\title{
MAPPING MOBILE MONEY IN RWANDA: THE MVISA PROJECT
}

\author{
Theodore Burikoko, \\ Esri Rwanda Ltd. \\ P.O.Box 6867, Kigali, Rwanda
}

\begin{abstract}
After launching a partnership with the Rwandan government to drive the country's payment system from a cash-based economy to a cashless one, Visa was the first - and until today the only - major credit card company to enter the Rwandan Market fully in 2012.

In July 2013 the Bank of Kigali together with VISA launched mVISA, an interoperable mobile branchless banking solution. The goal of mVISA is to meet the needs of underserved and unbanked Rwandans by providing relevant, affordable and accessible financial services. The mVISA product is a digital wallet that targets 55 per cent of the country's population of 10.5 million that currently have mobile phones.

It will allow clients to easily access their bank's account via their phone and also encourage non- account holders mainly rural folks to become bankable.

For VISA to achieve their goal of bringing millions of additional people to profit from digital payment, the general public needs to know where to find an mVisa agent who can pay real cash withdrawn or transferred from remote accounts. To address this challenge Visa Rwanda mandated an ArcGIS Online solution showing the location and additional details of all the newly established $\mathrm{mVisa}$ agents.

As there is no basis for an automated geocoding yet for the whole of the country (no street names, house numbers, etc.) the mVisa Agent locations have to be collected using a GPS. Using public transport and motorbike taxis in rural areas, each agent is visited and the data thus collected is uploaded to ArcGIS Online. The resulting map is updated on a monthly basis with newly registered agents and is shared with the general public. Currently mVisa is being used by Bank of Kigali (BK) and the Urwego Opportunity Bank (UOB).
\end{abstract}

\section{CLOUD-BASED PLATFORM FOR CREATING AND SHARING WEB MAPS}

\author{
Jean Pierre Gatera \\ Esri Rwanda Ltd.P.O. Box 6867, Kigali, Rwanda \\ Email:j.gatera@esri.rw
}

The rise of cloud computing is one the most important thing happening in information technology today. While many things are moving into the cloud, this trend has also reached the Geographic Information System (GIS) world. For the users of GIS technology, the cloud opens new possibilities for sharing web maps, applications and spatial data.

The goal of this presentation/demo is to demonstrate ArcGIS Online which is a cloud-based collaborative platform that allows to easily and quickly create interactive web maps that you can share with anyone. With readyto-use content, apps, and templates you can produce web maps right away. And no matter what you use - desktops, browsers, smartphones, or tablets - you always have access to your content.

ПРОБЛЕМЫ СТАНОВЛЕНИЯ РОССИЙСКИХ ИПД

\author{
A.В. Кошкарев \\ Институт географии РАН \\ Москва, Россия, akoshkarev@yandex.ru
}

PROBLEMS OF THE SDIS IMPLEMENTATION IN RUSSIA

\author{
A.V. Koshkarev \\ Institute of Geography RAS \\ Moscow, Russia, akoshkarev@yandex.ru
}


Abstract. A review of recent initiatives in the SDI implementation on national and regional levels in Russia, including its legislation, spatial data standards, geo-portals, spatial data, metadata and services is given.

Введение. Двадцатилетний опыт становления и развития информационно-телекоммуникационных систем, получивших название инфраструктур пространственных данных (ИПД) разного типа и назначения: национальных, региональных, локальных, ведомственных, корпоративных, научных и образовательных, дает богатую пищу для размышлений над их будущим. Переход геоинформатики от эпохи геоинформационных систем к эпохе ИПД дает убедительные примеры того, что дают и дадут новые информационно-телекоммуникационные технологии в совершенствовании механизмов управления пространственными данными и геоинформационными ресурсами в целом. Увы, эти примеры нужно искать за рубежом. Что же касается России - непосредственного объекта рассмотрения - ее успехи в деле геоинфраструктурного обустройства более чем скромны, а сам опыт фрагментарен, малоизучен и малоизвестен. Поэтому цель настоящего анализа - провести очередную «ревизию» того, что сделано в этой области в России на широком международном фоне, сославшись, по возможности, на все значимые инициативы последних лет в науке, образовании, бизнесе и государственном управлении. Их текущее состояние логично проанализировать с точки зрения того, как реализованы на сегодня отдельные компоненты ИПД: их нормативная правовая (законодательная) база, нормативно-техническая база (стандарты и иные подобные им нормы), сетевые сервисы (геосервисы), ресурсы пространственных данных, в том числе базовых, метаданные и механизмы инвентаризации и поиска данных и сервисов, геопорталы в качестве интерфейса пользователя ресурсами ИПД.

Анализ был бы не полон и, главное, неконструктивен, если не рассматривать ИПД-инициативы на фоне обширного международного опыта, тем более, что кое-что давно используется в отечественных разработках. Здесь, прежде всего, стоит упомянуть североамериканские и европейские программы.

Первой из национальных ИПД, положившей начало перехода от эпохи ГИС к эпохе ИПД, является ИПД США NSDI, созданная в 2000 г. в соответствии с Распоряжением Президента США У.Д. Клинтона от 13 апреля 1994 г. Перспективы ее развития определены в 1998 г. в докладе NAPA (Национальная академия общественного управления) «Географическая информация в XXI веке» (http://www.napawash.org/pc_management_studies/napa_report.html). Для прямого онлайнового доступа к пространственным данным или поиска необходимых данных в NSDI было создано шесть шлюзов с выходом в сеть национальных центров информационного обмена («клиринговых центров» - от англ. clearinghouse), объединяющую сотни серверов на территории США. На начало 2006 г. «архитектура» NSDI как «Системы Систем» представляла собой объединение Федерального комитета по географическим данным FGDC, координирующего органа NSDI, программ «Национальная карта» и «Национальный атлас», а также геопортала GOS (Geospatial One-Stop), реализующего принцип «одного окна». Геопортал был разработан в начале нулевых годов в рамках президентской программы «Электронного правительства» США как одна из 24 его инициатив. С мая 2009 г. для доступа к геоинформационным ресурсам NSDI используется новый cepвис Data.gov (http:/www.data.gov/), объединивший метаданные о более чем 400 тыс. федеральных наборов данных 172 агентств и организаций. Значительная часть данных доступна также на геопортале Geospatial Platform (http://www.geoplatform.gov). Нечто подобное - «портал открытых данных России», где можно отыскать и пространственные данные, - появился совсем недавно (http://data.gov.ru).

Еще более впечатляющий и достойный воспроизведения пример - программа создания Европейской ИПД, известная сейчас под именем программы Европейского союза INSPIRE (Infrastructure for Spatial Information in Europe), объединяющая усилия и ресурсы ее стран-участниц [Кошкарев 2009 б)]. Как идея и инициатива Европейской комиссии она известна с 2001 г. Работы над нею начались в 2005 г., в соответствии с ее рабочей программой, в которой выделены три этапа ее разработки: предварительный этап (2005-2006 гг.), переходный этап (2007-2009 гг.) и этап реализации вплоть по 2019 г. Важнейшим событием в истории развития программы и началом разработки ее нормативной правовой и нормативно-технической базы явилось утверждение и вступление в силу 15 мая 2007 г. Директивы INSPIRE (Директива 2007/2/EC Европейского парламента и Совета Европы от 14 марта 2007 г.). Первая версия текста Директивы INSPIRE была опубликована в 2004 г.; ее содержание достаточно близко к утвержденной и действующей ныне. Она нацелена на решение проблем, связанных с теми данными, которые необходимы для мониторинга окружающей среды и улучшения ее состояния, включая воздушную и водную среды, почвы и природные ландшафты. Тем не менее, она не предназначена для выработки какой-либо новой программы сбора пространственных данных в странах-членах ЕC, лишь предлагая разработку эффективных средств использования имеющихся данных и требуя документирования пространственных данных в виде метаданных, предоставления сервисов доступа к ним, обеспечения их интероперабельности (взаимосовместимости) и устранения препятствий в их использовании [Кошкарев, 2014].

Настоящий обзор построен на информационных ресурсах Всемирной паутины, включая геопорталы, научной и научно-технической литературе и результатах научно-исследовательских работ автора, отраженных в недавних обзорах [Кошкарев, 2009 a, 2010, 2012; Кошкарев, Ротанова, 2013; Антипов, Кошкарев, Потапов и др., 2013] и публикациях на тему нормативно-правой базы ИПД [Кошкарев, 2011, 2013], организации ее геопорталов [Кошкарев, 2008 а, б, в, 2009 б; Кошкарев, Тикунов, Тимонин, 2010], 
системы управления метаданными в их составе [Кошкарев, 2009 в], интеграции геоинформационных научных ресурсов при создании элементов академической ИПД [Кошкарев, Антипов, Батуев и др., 2008; Бакланов, Ермошин, Комедчиков и др., 2011; Кошкарев, Ряховский, Серебряков, 2010; Атаева, Кошкарев, Медведев и др., 2011; Кошкарев, Медведев, Серебряков, 2012; Комедчиков, Кошкарев, Медведев, 2013].

Нормативная правовая база ИПД. В строительстве ИПД и ее дальнейшем развитии заинтересован и широкий круг агентов геоинформационной деятельности и, в частности, геоинформационного рынка. Объединение усилий и ресурсов всех сторон в рамках информационно-телекоммуникационной системы нуждается в законодательном регулировании, а на этапе ее становления - и в поддержке, наделяя их правами и обязанностями. Опыт показывает, что вслед за идеей ИПд следует разработка концепции или стратегии ее создания и развития, далее уточняемая и конкретизируемая в законодательных документах, а на их основе - в программах и рабочих планах. Следуя этой естественной логике, такая концепция была подготовлена еще десятилетие назад, вначале в виде проектов Концепции ИПД РФ, разработанных в 2003 2004 гг. параллельно Роскартографией РФ и ГИС-Ассоциацией, а затем и их согласованного варианта, спустя два года одобренного распоряжением Правительства Российской Федерации от 21 августа 2006 г. \# 1157-p (http://base.consultant.ru/cons/cgi/online.cgi?req=doc;base=EXP;n=372580). Следующий логичный шаг федеральный закон - не сделан и сейчас. Не приняты давно ожидаемые поправки в Ф3 «О геодезии и картографии» в той его части, которая касается ИПД. Действующий ныне Ф3 «О геодезии и картографии» 1995 г. (http://docs.kodeks.ru/document/9015033\#) с некоторыми более поздними поправками уже не соответствуют сложившимся реалиям. Лишь через пять лет после утверждения Концепции ИПД РФ, в июле 2011 г., был опубликован проект Ф3 «Об ИПД, геодезической и картографической деятельности в Российской Федерации», разработанный в Минэкономразвития РФ, вынесенный на обсуждение на площадке ГИС-Ассоциации (http://www.gisa.ru/proekt_fz_ipd.html). Через год, в июле 2012 г., Минэкономразвития РФ опубликовал проект нового федерального закона, на этот раз под именем Ф3 «О геодезии, картографии и пространственных данных...» с предложением провести его антикоррупционную экспертизу (http://www.gisa.ru/ekspertiza_proekta_fz_o_geodezii.html). Поскольку нового закона нет до сих пор, в этих условиях разработки в области создания ИПД в РФ (и не только ИПД национального и регионального уровней) ведутся, по существу, в условиях правого вакуума». Все варианты законопроектов подверглись жесткой критике со стороны широкого геоинформационного сообщества. Их утверждение в том виде, как они были представлены, нанесло бы ощутимый вред процессам становления ИПД.

Тем не менее, на уровне субъектов РФ есть примеры регионального законотворчества в сфере ИПД; среди них:

Постановление Правительства Республики Башкортостан от 25.06.2012 г. № 206 «Об инфраструктуре пространственных данных Российской Федерации на территории Республики Башкортостан» (http://to02.rosreestr.ru/geodeziya_cartografiya /spatial_data_infrastructure/) и Постановление Правительства Республики Башкортостан от 11 марта 2013 г. № 77 «О республиканской целевой программе «Создание и развитие инфраструктуры пространственных данных Российской Федерации на территории Республики Башкортостан» на 2013 - 2018 годы» (http://www.garant.ru/hotlaw/bashkor/465463/).

Постановление Кабинета Министров Республики Татарстан от 26 марта 2012 г. № 239 «Об утверждении Положения об инфраструктуре пространственных данных на территории Республики Татарстан (http://www.zakonprost.ru/content/regional/65/1714840), разработанного на основе активного обсуждения его проекта (http://www.gisa.ru/file/file2167.doc) экспертами ГИС-Ассоциации и принятого по итогам обсуждения в качестве «Типового Положения о региональной Инфраструктуре пространственных данных субъекта РФ» (http://www.gisa.ru/file/file2220.doc).

Положение о «Региональной инфраструктуре пространственных данных (РИПД) Калужской области» (http://www.giskaluga.ru/About/News/polozhen_ripd.pdf).

Постановление Правительства Москвы от 30.06.2009 № 619-ПП «О Концепции среднесрочной городской целевой программы работ по развитию единого геоинформационного пространства города Москвы на 2010-2011 годы» (http://www.garant.ru/products/ipo/prime/doc/292230/) и «Постановление Правительства Москвы от 24.02.2010 № 162-ПП «О Среднесрочной городской целевой программе работ по развитию единого геоинформационного пространства города Москвы на 2010-2011 годы» (http://mosopen.ru/document/162_pp_2010-02-24).

Распоряжение Правительства Свердловской области от 03.11.2011 г. № 1998-РП «О создании Координационного совета по созданию и развитию инфраструктуры пространственных данных Свердловской области» (http://mugiso.midural.ru/upload/iblock/7e7/7e 7551ee9926028ba0015ff97acb0d18.pdf).

Проект Положения о региональной инфраструктуре пространственных данных Кировской области и проект регионального закона о ней (http://www.gisa.ru/ipd_kirov.html), обсуждавшийся на сайте ГИСАссоциации в марте 2014 г.

При всей значимости региональных уложений и заметном улучшении их содержания они не идеальны. К их существенным недостаткам, в частности, принадлежат: наделение ИПД несвойственной им функцией создания пространственных данных, неясность отношений регионального узла ИПД с федеральным центром, путаница в терминологии, невнимание к тематическим и отраслевым данным в составе информационных ресурсов ИПД, допущение закрытости некоторых категорий данных (существование «закрытых контуров» систем), отсутствие систем мониторинга их исполнения и указаний на этапность и календарные сроки реализации систем. 
В этом отношении показателен пример уже упомянутой Директивы INSPIRE как международного законодательного акта, предписывавшего в кратчайший срок привести в соответствии с ней законодательство отдельных стран участниц, что было выполнено в запланированный срок. Важно и то, что законодательные новости коснулись всей вертикальной системы их управления. Одним из первых подобных инициатив был Федеральный закон ФРГ «О доступе к цифровым пространственным данным» GDI-DE GeoZG ФРГ, принятый в феврале 2009 г. и ставший правовой основой для дальнейшего развития ИПД ФРГ в новом общеевропейском правовом пространстве, вслед за которым появились аналогичные законы уже федеральных земель и, логично предположить, муниципалитетов. Напомним, что Концепцией ИПД РФ тоже предусмотрено ее иерархическое трехуровневое устройство.

Стандарты ИПд. Необходимость в стандартизации ИПД вызвана тем, что она представляет собой сложную, гетерогенную, распределенную информационно-телекоммуникационную систему, в создание компонентов которой вовлечены различные государственные ведомства и агентства, регионы и органы местного самоуправления, коммерческие и академические структуры. Условием эффективности функционирования такой системы в распределенной сетевой среде является свойство интероперабельности элементов ее архитектуры, то есть способности ее систем работать совместно. Ее «работоспособность» поэтому в немалой степени определяется тем, насколько в своей деятельности они будут полагаться на стандарты, уже существующие или специально создаваемые для нужд ИПД, а также иные нормативные (нормативно-технические) документы, аналогичные стандартам, но отличные от них по статусу, либо дополняющие их содержание или определяющие порядок и механизмы их реализации (например, инструкции и руководящие документы) [Кошкарев, 2012].

ИПД строятся на международных стандартах и/или национальных и государственных стандартах, разрабатываемых с учетом международных. Используются стандарты трех организаций: ИСО, Европейского комитета по стандартизации CEN и консорциума OGC, Inc., покрывающих почти всю область стандартизации в области геоинформационных технологий.

ИСО ТК 211 (http://www.isotc211.org) - разработчик стандартов серии 19100 «Географическая информация». По состоянию на конец 2009 г. им разработаны 32 международных стандарта, 5 поправок, 7 технических спецификаций и 3 технических отчета. В ноябре 2011 г. список стандартов включал 39 единиц (часть из них находится в стадии пересмотра), 8 стандартов находились в процессе разработки. К ним ежегодно добавляется несколько документов. Сфера действия стандартов охватывает геоинформационные методы, средства и сервисы, используемые для целей управления, сбора, обработки, анализа, визуализации пространственных данных, доступа к ним, обмена ими в цифровой и электронной формах между различными пользователями и системами, опираясь на более общие международные стандарты в области информационно-телекоммуникационных технологий.

Стандартизаций в области геоинформатики и ИПд на европейском уровне занимается Технический комитет Европейского комитета по стандартизации CEN/NC 278 «Geographic information» (Географическая информация), образованный в 1992 г. (http://www.gistandards.eu). В 2005 г., после коренной реорганизации в 2003 г., работа комитета строится на адаптации международных стандартов ИСО серии 19100. В 2005-2006 г. было утверждено в качестве европейских 14 стандартов этой серии в дополнение к ранее подготовленным (до 1999 г.). Всего, по состоянию на ноябрь 2011 г., комитетом разработан 41 документ, из них 40 стандартов на основе стандартов ИСО, включая 39 стандартов серии ИСО 19100, и технический отчет CEN/TR 15449:2011 Geographic information - Standards, specifications, technical reports and guidelines, required to implement Spatial Data Infrastructures (Географическая информация стандарты, спецификации, технические отчеты и основные принципы, необходимые для реализации инфраструктуры пространственных данных), текст проекта которого известен в русском переводе (http:/www.gisa.ru/31541.html). В плане стандартизации комитета на период 2011-2014 гг. еще 14 документов, из них 11 адаптированных стандартов ИСО серии 19100 и три технических отчета собственной разработки, объединенных рубрикой «Инфраструктура пространственных данных».

Стандарты ИСО и CEN образуют основу систему стандартизации программы INSPIRE.

Еще один международный орган, разрабатывающий международно-признанные стандарты в области геоинформатики, в том числе ИПД, - консорциум OGC, Inc. (Open Geospatial Consortium: http://www.opengeospatial.org), созданный в 1994 г. и объединяющий крупные компании, государственные и академические организации общим числом 437 членов (на разных условиях членства). Цель деятельности консорциума - разработка спецификаций, обеспечивающих интероперабельность пространственных данных, сервисов и информационных систем, и их внедрение. Его де-факто стандарты именуются спецификациями (Open GIS® Specifications). Консорциум OGC - признанный лидер в области стандартизации сетевых сервисов и геосервисов, интероперабельных технологических решений для беспроводных сетей, сервисов, основанных на определении местоположения, навигационных сервисов. На основе его стандартных спецификаций созданы многие стандарты ИСО (а вслед за ними и СEN). Следует подчеркнуть, что стандарты всех перечисленных организаций являются «открытыми» стандартами в отличие от «закрытых», разрабатываемых крупными промышленными предприятиями и корпорациями в сфере информационно-телекоммуникационных технологий и, в частности, ГИС, охраняемых законами об авторских правах и/или требующих лицензий на их использование.

В России стандартами в области геоинформатики занимался Технический комитет по стандартизации ТК 394 «Географическая информация/геоматика» Ростехрегулирования РФ (http://www.tk394.ru), который 
является российским аналогом Технического комитета ИСО ТК 211 «Географическая информация/геоматика» (ISO/TC 211 «Geographic information/Geomatics), источника международных стандартов в области геоинформатики серии ИСО 19100. Комитет готовит или должен готовить российские национальные стандарты и профили международных стандартов ИСО. К сожалению, из 14 разработанных им стандартов непосредственное отношение к проблематике ИПД имеют два: «ГОСТ Р 53339-2009 Данные пространственные базовые. Общие требования» и «ГОСТ Р 52571-2006 Географические информационные системы. Совместимость пространственных данных. Общие требования». К стандартам, разработанным на основе стандартов ИСО серии 19100, которые тоже надо иметь в виду, относятся: «ГОСТ Р ИСО 19105-2003 Географическая информация. Соответствие и тестирование», «ГОСТ Р ИСО 19113-2003 Географическая информация. Принципы оценки качества», «ГОСТ Р 52572-2006 Географические информационные системы. Координатная основа. Общие требования» и «ГОСТ Р 52573-2006 Географическая информация. Метаданные».

На протяжении последних четырех лет работа комитета фактически заморожена.

В этих условиях при реализации ИПД РФ и ее региональных узлов напрямую или в виде национальных стандартов и иных документов технического регулирования могут быть использованы международные стандарты ИСО, основанные на них документы программы INSPIRE, спецификации Консорциума OGC, Inc. и иные стандарты. Это вполне соответствует основным принципам технического регулирования в РФ, установленным Федеральным законом «О техническом регулировании» от 27.12.2002 N 184-Ф3 (Статья 12), среди которых применение «международного стандарта как основы разработки национального стандарта, за исключением случаев, если такое применение признано невозможным вследствие несоответствия требований международных стандартов климатическим и географическим особенностям Российской Федерации, техническим и (или) технологическим особенностям или по иным основаниям либо Российская Федерация в соответствии с установленными процедурами выступала против принятия международного стандарта или отдельного его положения» (http://www.consultant.ru/popular/techreg/45_3.html\#p399). Этим же законом (статья 13, с учетом поправок Ф3 от 30.12.2009 N 385-Ф3) к числу документов в области стандартизации, используемым на территории Российской Федерации, среди прочих относятся (http://www.consultant.ru/popular/techreg/45_3.html\#p461): 1) международные стандарты, региональные стандарты, региональные своды правил, стандарты иностранных государств и своды правил иностранных государств, зарегистрированные в Федеральном информационном фонде технических регламентов и стандартов; 2) надлежащим образом заверенные переводы на русский язык международных стандартов, региональных стандартов, региональных сводов правил, стандартов иностранных государств и сводов правил иностранных государств, принятые на учет национальным органом Российской Федерации по стандартизации.

Стала обычной практика прямого использования оригинальных международных стандартов, в том числе при разработке компонентов ИПД РФ. В 2011 г. завершена работа по анализу и адаптации законодательных актов и нормативных документов программы INSPIRE [Создание и развитие, 2011], использованная, в частности, при разработке национального геопортала ИПД РФ.

Ресурсы пространственных данных. Среди разнообразных национальных информационных ресурсов можно выделить геоинформационные ресурсы, существенная часть которых составляют пространственные данные, другую же, не столь многочисленную, но важную часть занимают сетевые сервисы, поддерживающие их существование в сетевой среде.

Первая из задач, обычно решаемая на первом этапе реализации национальных ИПД - инвентаризация наличных пространственных данных для оценки их объема и разнообразия, и лишь затем их описание в форме метаданных, что обеспечивает их эффективный поиск.

В ИПД можно выделить три категории данных: 1) тематических, покрывающих все многообразие предметных областей, аналогами которых могут служить тематические карты и комплексные, в том числе национальные атласы доцифровой эпохи; 2) отраслевых, генерируемых министерствами и ведомствами, например, наборы топографических или морских навигационных данных; 3) базовых, нужных и востребованных широким кругом потребителей.

Представление о тематическом разнообразии данных ИПД может дать Директива INSPIRE. B трех приложениях к ней определены 34 темы, данные и метаданные по которым должна иметь каждая из стран Европейского союза к тому или иному сроку. Важно, что требования к этим данным, безусловно обязательные для всех стран-участниц Евросоюза, оформлены в виде «спецификаций», то есть де-факто стандартов (http://inspire.jrc.ec.europa.eu/index.cfm/pageid/2):

Приложение I.

1. Системы координат.

2. Регулярные географические сетки.

3. Географические названия.

4. Административные единицы.

5. Адреса.

6. Земельные участки.

7. Транспортные сети.

8. Гидрография. 
9. Особо охраняемые территории.

Приложение II.

1. Рельеф.

2. Земной покров.

3. Ортоизображения.

4. Геология.

Приложение III.

1. Статистические единицы.

2. Строения.

3. Почвы.

4. Использование земель.

5. Здравоохранение и безопасность среды обитания.

6. Коммунальное хозяйство и социальные службы.

7. Объекты экологического мониторинга.

8. Производство и индустриальные сооружения.

9. Объекты сельского хозяйства и аквакультуры.

10. Демография.

11. Управление территориями / Ограничения / Особые зоны и отчетность.

12. Зоны природных рисков.

13. Атмосферные условия.

14. Метеорология.

15. Океанографические объекты.

16. Морские регионы.

17. Биогеографическое районирование.

18. Местообитания и биотопы.

19. Биологическое разнообразие

20. Энергетические ресурсы.

21. Минеральные ресурсы.

Некоторые из них могут быть отнесены к категории базовых в их традиционном понимании. Однако большая часть тем относится к тематическим (отраслевым данным). Каково это соотношение в реально действующих ИПД, будет продемонстрировано ниже на примере данных, доступных на геопортале программы INSPIRE. В России задача инвентаризации и метаописания остальных, тематических пространственных данных на государственном уровне не ставится вообще. Отсутствуют и сами БПД, несмотря на гипертрофированное внимание к ним во всех документах и дискуссиях по поводу будущего развития ИПД РФ и его региональных узлов, а предлагаемые эрзацы в виде цифровых топографических карт или Единой электронной картографической основы (ЕЭКО) не могут решить давно назревших проблем, связанных с катастрофическим устареванием картографических источников, включая цифровые карты, и их низким качеством в целом, сохранением режима секретности существенной доли топографических данных и данных дистанционного зондирования Земли. Табл. 1 иллюстрирует разночтения в предлагаемых списках БПД ИПД РФ, то есть в национальном стандарте ГОСТ Р 53339-2009, проекте федерального закона (законопроекта) «Об инфраструктуре пространственных данных, геодезической и картографической деятельности в Российской Федерации» 2011 г. (http://www.gisa.ru/proekt_fz_ipd.html), в проекте Ф3 «О геодезия, картографии и пространственных данных...» $2012 \quad$ г (http://www.gisa.ru/ekspertiza proekta fz o geodezii.html) и «Проекте положения об ИПД Кировской области» (http://www.gisa.ru/ipd_kirov.html) в сравнении с перечнем в последней колонке, который предложен автором (http://www.gisa.ru/76515.html) и был неоднократно опубликован [Кошкарев, 2011, 2012]. 
Таблица 1

Соответствие предметных областей в предлагаемых перечнях наборов базовых пространственных данных

\begin{tabular}{|c|c|c|c|c|}
\hline $\begin{array}{c}\text { Базовые пространственные } \\
\text { объекты по ГОСТ Р 53339-2009 }\end{array}$ & $\begin{array}{c}\text { БПД согласно статей 7, } 10 \text { и } 11 \\
\text { проекта ФЗ «Об } \\
\text { инфраструктуре } \\
\text { пространственных данных...» } \\
2011 \text { г. }\end{array}$ & $\begin{array}{c}\text { БПД согласно статьи } 9 \text { проекта } \\
\text { Ф3 «О геодезии, картографии и } \\
\text { пространственных данных...» } \\
2012 \text { г. }\end{array}$ & $\begin{array}{c}\text { БПД и фундаментальные } \\
\text { данные регионального уровня } \\
\text { согласно проекта «Положения } \\
\text { о региональной ИПД } \\
\text { Кировской области }\end{array}$ & $\begin{array}{c}\text { Предлагаемый перечень } \\
\text { наборов БПД (предмет } \\
\text { обсуждения) }\end{array}$ \\
\hline Геодезические пункты & $\begin{array}{l}\text { Реестр государственных } \\
\text { геодезических сетей }\end{array}$ & $\begin{array}{l}\text { Координатная система отсчета } \\
\text { Российской Федерации, } \\
\text { пункты государственных } \\
\text { геодезических сетей }\end{array}$ & $\begin{array}{l}\text { Параметры используемой } \\
\text { местной системы координат } \\
\text { Кировской области; сведения о } \\
\text { пунктах сетей сгущения } \\
\text { Государственной } \\
\text { геодезической сети; } \\
\text { сведения о постоянно } \\
\text { действующей региональной } \\
\text { спутниковой } \\
\text { дифференциальной сети } \\
\text { референцных станций } \\
\text { Кировской области и данные } \\
\text { навигационно-геодезических } \\
\text { услуг на ее базе }\end{array}$ & Геодезические пункты \\
\hline $\begin{array}{l}\text { Единицы территориального } \\
\text { деления }\end{array}$ & $\begin{array}{l}\text { Реестр административных } \\
\text { границ }\end{array}$ & $\begin{array}{l}\text { Границы между субъектами } \\
\text { Российской Федерации, } \\
\text { муниципальными } \\
\text { образованиями и населенными } \\
\text { пунктами; государственная } \\
\text { границе РФ }\end{array}$ & $\begin{array}{l}\text { Границы Кировской области, } \\
\text { муниципальных образований и } \\
\text { населенных пунктов }\end{array}$ & $\begin{array}{l}\text { Единицы территориального } \\
\text { деления }\end{array}$ \\
\hline Объекты кадастрового деления & - & - & $\begin{array}{l}\text { Единицы кадастрового деления } \\
\text { и земельных участков, } \\
\text { учтенных в ГКН }\end{array}$ & $\begin{array}{l}\text { Данные кадастра } \\
\text { недвижимости }\end{array}$ \\
\hline Земельные участки & - & - & - & - \\
\hline Лесные кварталы & Объекты лесного фонда & - & Объекты лесного фонда & - \\
\hline $\begin{array}{l}\text { Поверхностные водные } \\
\text { объекты }\end{array}$ & Водные объекты & - & $\begin{array}{l}\text { Поверхностные объекты } \\
\text { водного фонда }\end{array}$ & $\begin{array}{l}\text { Поверхностные водные } \\
\text { объекты }\end{array}$ \\
\hline Объекты транспортной сети & $\begin{array}{l}\text { Объекты транспортной и } \\
\text { инженерной инфраструктуры }\end{array}$ & - & $\begin{array}{l}\text { Линейные объекты } \\
\text { федерального, регионального и } \\
\text { местного значения }\end{array}$ & Транспортная сеть \\
\hline
\end{tabular}




\begin{tabular}{|c|c|c|c|c|}
\hline & & & $\begin{array}{l}\text { (автодорожная и } \\
\text { железнодорожная сети, } \\
\text { трубопроводы, электросети и } \\
\text { др.) }\end{array}$ & \\
\hline $\begin{array}{l}\text { Особо охраняемые природные } \\
\text { объекты }\end{array}$ & - & - & $\begin{array}{l}\text { Особо охраняемые природные } \\
\text { территории }\end{array}$ & $\begin{array}{l}\text { Особо охраняемые природные } \\
\text { территории }\end{array}$ \\
\hline Закрытые объекты & - & - & & - \\
\hline Строения & $\begin{array}{l}\text { Объекты капитального } \\
\text { строительства }\end{array}$ & - & $\begin{array}{l}\text { Объекты капитального } \\
\text { строительства (здания и } \\
\text { сооружения) с адресной } \\
\text { информацией }\end{array}$ & - \\
\hline- & Реестр высот & - & - & $\begin{array}{l}\text { Цифровая модель рельефа } \\
\text { суши }\end{array}$ \\
\hline- & Реестр населенных пунктов & - & - & - \\
\hline- & $\begin{array}{l}\text { Государственные } \\
\text { ортофотокарты и } \\
\text { ортофотопланы }\end{array}$ & - & $\begin{array}{l}\text { Географически привязанные и } \\
\text { геометрически корректные } \\
\text { ортофотоизображения } \\
\text { Кировской области }\end{array}$ & Ортоизображения \\
\hline- & $\begin{array}{l}\text { Государственные } \\
\text { топографические карты и } \\
\text { планы }\end{array}$ & - & $\begin{array}{l}\text { Региональная } \\
\text { картографическая основа }\end{array}$ & - \\
\hline- & Реестр метаданных & - & - & - \\
\hline- & - & - & - & Электронный газеттир \\
\hline- & - & - & - & Адресный реестр \\
\hline- & - & - & $\begin{array}{l}\text { Территории объектов } \\
\text { культурного наследия }\end{array}$ & Объекты культурного наследия \\
\hline- & - & - & $\begin{array}{l}\text { Зоны с особыми условиями } \\
\text { использования территорий }\end{array}$ & - \\
\hline- & - & - & $\begin{array}{l}\text { Территории, подверженные } \\
\text { риску возникновения } \\
\text { чрезвычайных ситуаций } \\
\text { природного и техногенного } \\
\text { характера }\end{array}$ & - \\
\hline- & - & - & Территориальные зоны & - \\
\hline- & - & - & «Красные» линии & - \\
\hline
\end{tabular}

Примечание: серым фоном выделены данные, относимые авторами проекта к «фундаментальным», целесообразность чего вызывает сомнения 
Метаданные. Для описания пространственных данных разработаны и давно используются стандарты на содержание и формы представления описаний данных. Первым из них был американский стандарт CSDGM (Content Standard for Digital Geospatial Metadata), впервые разработанный в 1992 г. и известный сейчас как стандарт Федерального комитета США по географическим данным FGDC-STD-001-1998 (http://www.fgdc.gov/standards/projects/FGDC-standards-projects/metadata/base-metadata/index_html).

Сегодня системы управления метаданными национальных и иных ИПД строятся на основе международных стандартов. По такому пути давно идут и российские разработчики ИПД и геопорталов, хотя не везде и не всегда.

Общая ситуация, сложившаяся в настоящее время в России, такова [Кошкарев, 2012].

Государственными структурами, научными и учебными организациями и предприятиями бизнеса в той или иной мере используются следующие международные, зарубежные и российские стандарты на содержание пространственных метаданных:

- ГОСТ Р 52573-2006 «Географическая информация. Метаданные»,

- ISO 19115:2003 «Geographic information - Metadata» (ИСО 19115:2003 «Географическая информация - Метаданные»),

- ISO 19115-2: 2009 «Geographic information - Metadata - Part 2: Extensions for imagery and gridded data» (ИСО 19115-2: 2009 «Географическая информация - Метаданные» - Часть 2: Расширения для растровых изображений и данных в форме сеточных моделей),

- ISO 19119:2005: «Geographic information - Services» (ИСО 19119:2005 «Географическая информация - Сервисы»),

- FGDC-STD-001-1998 «Content Standard for Digital Geospatial Metadata»(CSDGM), version 2, US Federal Geographic Data Committee (стандарт Федерального комитета по географическим данным США FGDC),

- Dublin Core (Дублинское ядро, включая ISO 15836:2009 «Information and documentation - The Dublin Core metadata element set»), ГОСТ Р 52573-2006 «Географическая информация. Метаданные»,

- ГОСТ Р 51353-99 «Геоинформационное картографирование. Метаданные электронных карт. Состав и содержание».

• Профиль программы INSPIRE на основе международных стандартов ИСО 19115/ИСО 19119.

Практически все они реализованы (за исключением ГОСТ Р 51353-99, непригодного для реализации) с использованием стандарта ISO 19139:2007 «Geographic information - Metadata - XML schema implementation» (ИСО 19139:2007 «Географическая информация - Метаданные - Реализация в языке ХML). Распространены и не стандартизованные проприетарные (собственной разработки) схемы метаописаний. Наиболее популярным стандартом является ИСО 19115:2003 благодаря его поддержке наиболее популярными в России зарубежными коммерческими программными средствами ГИС, опережая по числу реализаций национальный стандарт ГОСТ Р 52573-2006.

Достаточно открыть любой из наборов данных российского национального геопортала, например, номенклатурный лист О-35-094-А-а открытой цифровой топографической карты масштаба 1:25000, которая хранится ФГБУ «Федеральный научно-технический центр геодезии, картографии и инфраструктуры пространственных данных», и в описании данных, среди прочих элементов метаданных, мы увидим (http://nsdi.ru/geoportal/catalog/search/resource/details.page?uuid=\%7B5F0FEBCB-D661-4E6A-9B101E03F25546DE\%7D):

Стандарт метаданных: ISO 19139/19115 Metadata for Datasets

Версия стандарта метаданных: 2003 (рис. 1):

Чтобы убедиться, что это действительно так, откроем полное описание набора данных в языке XML

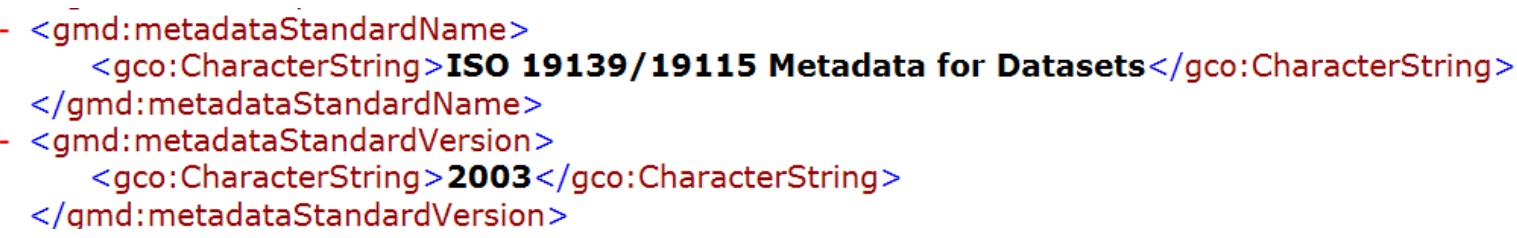

Рис. 1. Фрагмент описания метаданных в языке XML на геопортале ИПД РФ (http://nsdi.ru/geoportal/rest/document?id=\%7B5F0FEBCB-D661-4E6A-9B10-1E03F25546DE\%7D)

Как следует из руководства пользователя геопортала (http://nsdi.ru/geoportal/catalog/docs/help.pdf), его возможности ограничены следующими стандартами на содержание метаданных и сервисы, куда не входит наш российский профиль ГОСТ Р 52573-2006, цитирую: 
«Геопортал позволяет создавать метаданные в стандартном редакторе в соответствии со следующими стандартами:

FGDC
Dublin Core
North American Profile (Данные)
North American Profile (Сервисы)
GEMINI (Data)
GEMINI (Services)
ISO 19115 (Данные)
ISO 19119 (Сервисы)
ISO $19115-2$ (Изображения и данные с географической привязкой)».

Следуя общей тенденции гармонизации российской нормативно-технической базы с европейской, примером которой служит национальный российский геопортал, можно рекомендовать использование профиля метаданных программы INSPIRE, как это установлено на уровне законодательства Европейского союза (http://eur-lex.europa.eu/LexUriServ/LexUriServ.do?uri=OJ:L:2008:326:0012:0030:EN:PDF) и детально закреплены соответствующими правилами.

Главная особенность профиля стандарта INSPIRE - включение в его состав элементов стандарта ИСО 19119:2005 «Географическая информация - Сервисы». Это связано, прежде всего, с широким распространением веб-сервисов (геосервисов), число которых, доступных на существующих геопорталах, достигает десятков и сотен, поэтому их эффективный поиск представляет собой проблему и возможен лишь при условии их описания в виде метаданных, подобно метаописанию пространственных данных по стандарту ИСО 19115 и его профилям. Такое расширение элементного состава ИСО 19115 - примечательная тенденция последних лет. Возможность поиска геосервисов (прежде всего, картографических веб-сервисов, использующих стандартные спецификации Консорциума OGC, Inc.: WMS, WCS, WFS и др.) реализована на полнофункциональных национальных геопорталах. Вторая особенность профиля INSPIRE - он позволяет описывать не только наборы пространственных данных (как, к примеру, ГОСТ Р 52573-2006), но и их серии (ГОСТ Р 52573-2006 не унаследовал такую возможность), заменяя, при необходимости, описания индивидуальных, схожих по своим свойствам продуктов описаниями их коллекций.

Геопорталы. Под геопорталом обычно понимается «точка входа в Интернет или интранет с инструментами просмотра метаданных, поиска географической информации, ее визуализации, загрузки, распространения и, возможно, поиска геосервисов», или, короче, сайт, обеспечивающий доступ к сервису поиска пространственных данных по метаданным, а также к другим сетевым сервисам в соответствии с его назначением и целевой аудиторией. Геопорталы можно рассматривать как площадку для взаимодействия производителей (правообладателей) пространственных данных и их пользователей, средство распространения данных и обмена ими, единую точку входа в сеть серверов, средство доступа к распределенным ресурсам пространственных данных, геосервисов и геоприложений. Каждая ИПД должна иметь, по крайней мере, один геопортал.

К числу реальных инициатив, которые можно записать в «актив» ИПД РФ, нужно отнести ее геопортал, введенный в эксплуатацию в марте 2012 г. и официально открытый с июля 2012 г. (рис. 2). Правда, по состоянию на март 2014 г., он до сих пор находится в режиме тестирования. Сравним структуру и число наборов данных на нем и на геопортале программы INSPIRE (рис. 3). Очевидно, что геопортал ИПД РФ содержит исключительно данные по двум предметным областям «Картография» и «Транспорт», то есть топографические и навигационные карты (табл. 2). Первые три графы таблицы копируют текст ГОСТ Р 52573-2006 с наименованием предметных областей. Для сравнения приведены данные геопортала программы INSPIRE с гораздо более сбалансированной структурой информационных ресурсов, включая наборы данных и их серии (без геосервисов, не учтенных при запросе на поиск). Ранее нами приводились и более развернутые данные о ее информационных ресурсах [Кошкарев, 2014]. Например, поиск цифровых моделей рельефа из числа 17275 описанных в виде метаданных на территорию Европейского союза (тема «Рельеф» Приложения II к Директиве) обнаружил 182 наборов данных Испании, в том числе матрицу высотных отметок с шагом 5 м., созданную в процессе фотограмметрической обработки снимков по программе PNOA (долгосрочной национальной программе высоко детальной аэрофотосъемки). Число опубликованных метаданных о рельефе существенно разнится по странам ЕС: от 1545 для территории Польши до одного набора данных для территорий Ирландии, Люксембурга, Нидерландов и Словакии. Другой пример: 1869 ортоизображений (http://inspire-geoportal.ec.europa.eu/discovery/). Напомним, что спецификацией набора данных «Ортоизображения» в Директиве INSPIRE, предусмотрено их пороговое пространственное разрешение 0.1 м при наличии реальных данных в диапазоне 0.25-0.30 м. На геопортале ИПД США NSDI в то же самое время (2010.02.09) можно было отыскать 4464 ортоизображения из общего числа 88798 доступных

(http://catalog.data.gov/dataset?q=Orthoimagery\&sort=none\&ext_location=\&ext_bbox=\&ext_prev_extent=139.21874999999997\%2C8.754794702435618\%2C-61.87499999999999\%2C61.77312286453146). 
В последние годы предложены и реализованы технологические решения, позволившие создать полнофункциональные или функционально ограниченные геопорталы в регионах. Первым из них был геопортал электронного правительства Самарской области (http://geosamara.ru). На сегодняшний день наиболее полнофункциональным можно считать геопортал Воронежской области (http://map.govvrn.ru). Наличие функций поиска данных по метаданным позволяет отнести к числу «истинных» и «Отраслевой узел Единого геоинформационного пространства города Москвы» (интегрированную автоматизированную информационную систему) (http://egip.mka.mos.ru/egip/egip.nsf/). Из недавних примеров нужно упомянуть геоинформационный портал Чувашии (http://sdi.cap.ru/geoportal/catalog/main/home.page) в составе ИПД Чувашской Республики и геопортал Республики Коми (http://gis.rkomi.ru/).

Не все региональные геопорталы соответствуют своему назначению. Напомним, что абсолютно обязательной функцией геопортала в составе ИПД является функция поиска данных и сервисов по метаданным; остальные сервисы, доступ к которым обеспечивает геопортал, включая сервис визуализации данных, являются факультативными. Не являются геопорталами в точном соответствии с их определением «геопорталы» (геоинформационные порталы) Ульяновской (http://gis.ulgov.ru/), Белгородской (http://www.map31.ru/), Кировской (http://geoportal43.ru/, http://kirov.rekod.ru/), Архангельской областей (http://maps29.ru) Приморского края (http://www.primoragp.ru/geoportal). Это сервисы вебкартографирования, ошибочно относимые к элементам ИПД.

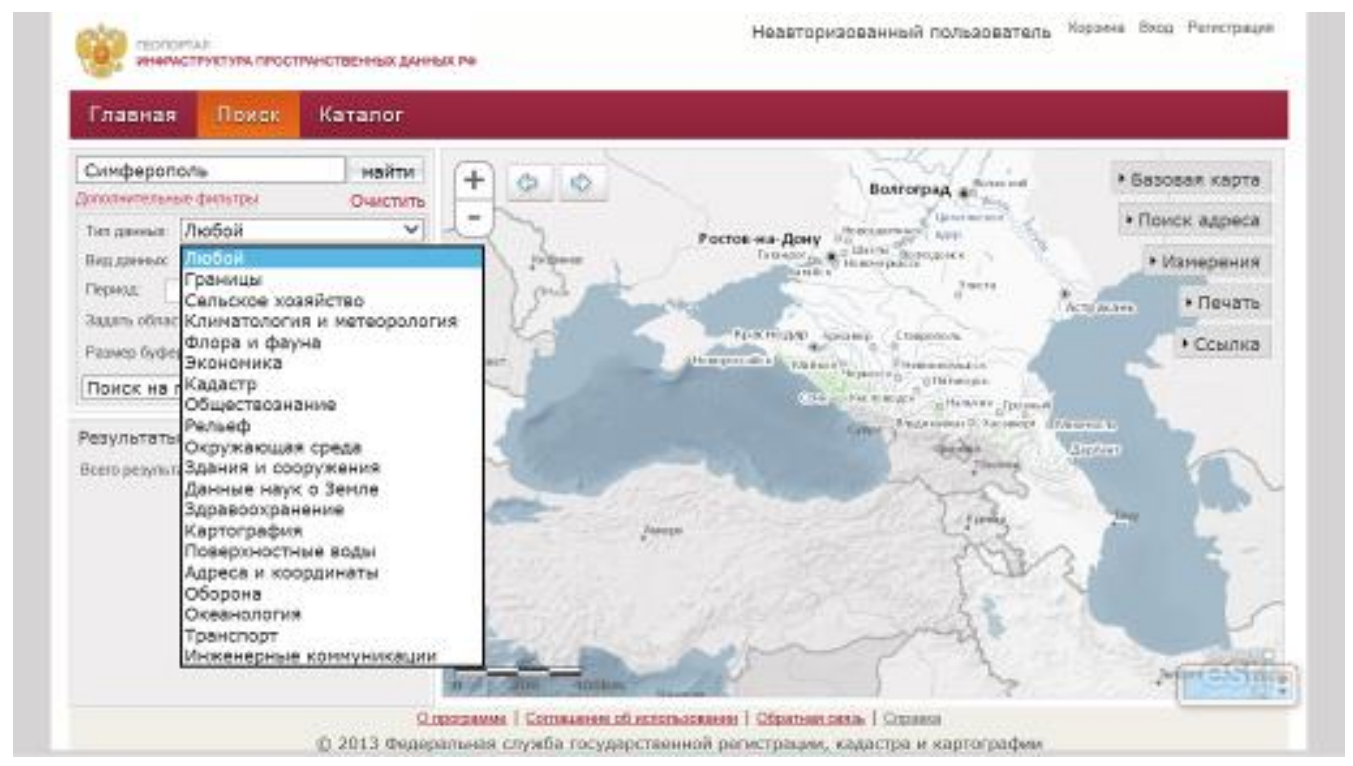

Рис. 2. Окно поиска данных по их метаданным на геопортале ИПД РФ (http://nsdi.ru/geoportal/catalog/search/search.page)

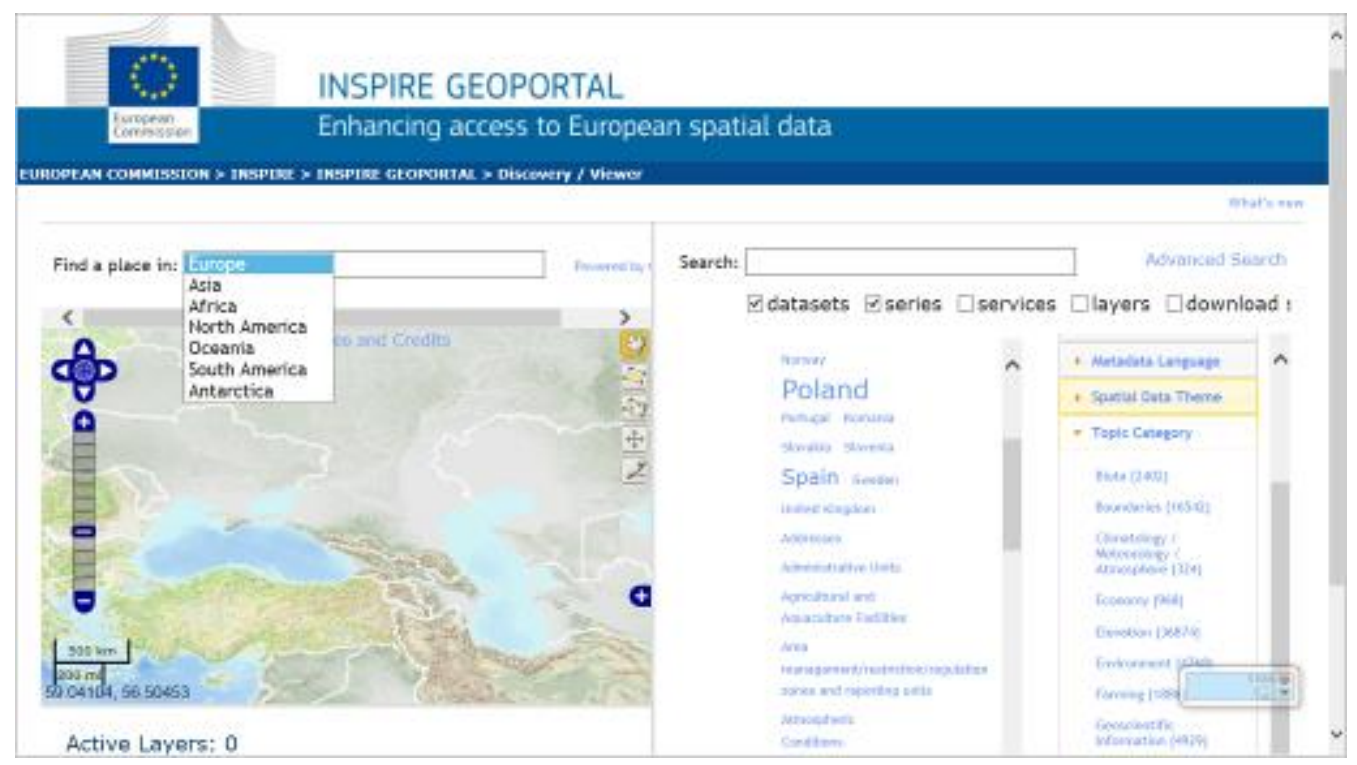

Puc. 3. Окно поиска данных по их метаданнымм на геопортале INSPIRE (http://inspiregeoportal.ec.europa.eu/discovery/\#). На правой панели - число наборов данных по предметным областям согласно стандарту ISO 19115:2003 
Число наборов данным по предметным областям («Enumeration») стандарта ГОСТ Р 52573-2006

\begin{tabular}{|c|c|c|c|c|}
\hline $\begin{array}{c}\text { Наименование в передаче на } \\
\text { русский и в оригинале }\end{array}$ & Домен & Описание & \multicolumn{2}{|c|}{$\begin{array}{c}\text { Число наборов данных на геопорталах (по } \\
\text { состоянию на 26.03.2014 г.) }\end{array}$} \\
\hline 1 MD_TopicCategoryCode & TopicCatCd & Описание предметных областей & INSPIRE & ИПД РФ \\
\hline 2 Сельское хозяйство/Farming & 001 & $\begin{array}{l}\text { Животноводство, растениеводство. Например: земледелие, } \\
\text { лесонасаждения, выращивание животных, разведение } \\
\text { растений }\end{array}$ & 1886 & 0 \\
\hline 3 Флора и фауна/Biota & 002 & $\begin{array}{l}\text { Флора и фауна естественной среды. Например: живая } \\
\text { природа, растительность, биология, экология, заболоченные } \\
\text { территории и т.д. }\end{array}$ & 2402 & 0 \\
\hline 4 Границы/Boundaries & 003 & $\begin{array}{l}\text { Государственные границы и административно- } \\
\text { территориальное деление. Например: границы субъектов, } \\
\text { районов, государств }\end{array}$ & 16542 & $1^{* * *}$ \\
\hline $\begin{array}{l}5 \text { Климатология и } \\
\text { метеорология/Climatology/ } \\
\text { Meteorology/Atmosphere }\end{array}$ & 004 & $\begin{array}{l}\text { Процессы и явления атмосферы. Например: облачность, } \\
\text { погода, климат, атмосферные условия, климатические } \\
\text { изменения, выпадение осадков и т.д. }\end{array}$ & 324 & 0 \\
\hline 6 Экономика/Economy & 005 & $\begin{array}{l}\text { Описание экономических аспектов деятельности, состояния } \\
\text { экономики в целом, занятости населения и т.д. Например: } \\
\text { производство, торговля, промышленность, туризм и } \\
\text { экотуризм, лесничество, рыболовство, добыча полезных } \\
\text { ископаемых и др. }\end{array}$ & 968 & 0 \\
\hline 7 Рельеф/Elevation & 006 & $\begin{array}{l}\text { Высота выше или ниже уровня моря. Например: высота над } \\
\text { уровнем моря, батиметрия, цифровые модели рельефа, угол } \\
\text { наклона и т.д. }\end{array}$ & 36874 & 0 \\
\hline $\begin{array}{l}8 \text { Окружающая } \\
\text { среда/Environment }\end{array}$ & 007 & $\begin{array}{l}\text { Экологические ресурсы, их защита и охрана. Например: } \\
\text { загрязнение окружающей среды, захоронение отходов, } \\
\text { экологическая экспертиза, мониторинг экологических рисков, } \\
\text { природные охраняемые территории, ландшафт и т.д. }\end{array}$ & 4768 & 0 \\
\hline $\begin{array}{l}9 \text { Данные наук о } \\
\text { Земле/Geoscientific } \\
\text { Information }\end{array}$ & 008 & $\begin{array}{l}\text { Наука о Земле. Например: геофизические характеристики и } \\
\text { процессы, геология, полезные ископаемые, структура и } \\
\text { происхождение горных пород, риск землетрясений, } \\
\text { вулканическая активность, оползни, вечная мерзлота, } \\
\text { гидрогеология и т.д. }\end{array}$ & 4929 & $0(1)^{*}$ \\
\hline 10 Здравоохранение/Health & 009 & $\begin{array}{l}\text { Здоровье, медицинское обслуживание, экология и } \\
\text { безопасность. Например: болезни, факторы, влияющие на } \\
\text { здоровье, гигиена, медицинское обслуживание и т.д. }\end{array}$ & 705 & 0 \\
\hline 11 Картография/Imagery/Base & 010 & Картографические материалы. Например: топографические & 198104 & $449212^{* * * *}$ \\
\hline
\end{tabular}




\begin{tabular}{|c|c|c|c|c|}
\hline Maps/Earth Cover & & $\begin{array}{l}\text { карты, схемы, планы городов, аэрокосмические изображения } \\
\text { и т.д. }\end{array}$ & & \\
\hline $\begin{array}{l}12 \\
\text { Оборона/Intelligence/Military }\end{array}$ & 011 & $\begin{array}{l}\text { Структура и деятельность вооруженных сил, военные базы. } \\
\text { Например: казармы, военная подготовка, военный транспорт }\end{array}$ & 616 & 0 \\
\hline $\begin{array}{l}13 \text { Поверхностные } \\
\text { воды/Inland Waters }\end{array}$ & 012 & $\begin{array}{l}\text { Объекты внутренних вод, дренажные системы и их } \\
\text { характеристики. Например: реки и ледники, соленые озера, } \\
\text { планы использования воды, дамбы, потоки, наводнения, } \\
\text { качество воды, гидрографические карты }\end{array}$ & 5748 & 0 \\
\hline $\begin{array}{l}14 \text { Координатные и адресные } \\
\text { данные/Location }\end{array}$ & 013 & $\begin{array}{l}\text { Информация о местонахождении и соответствующие службы. } \\
\text { Например: адреса, геодезические сети, опорные точки, } \\
\text { почтовые зоны и службы, географические названия }\end{array}$ & 54893 & 0 \\
\hline 15 Океанология/Oceans & 014 & $\begin{array}{l}\text { Возможности и характеристики соленых вод (исключая } \\
\text { поверхностные воды). Например: колебания, приливная } \\
\text { волна, информация о прибрежной зоне, рифы }\end{array}$ & 5237 & 0 \\
\hline 16 Кадастр/Planning/Cadastre & 015 & $\begin{array}{l}\text { Систематизированный свод сведений о природном, правовом } \\
\text { и хозяйственном положении Земли. Например: дежурные } \\
\text { кадастровые карты, вспомогательные карты, кадастровые } \\
\text { исследования }\end{array}$ & 72388 & 0 \\
\hline 17 Обществознание/Society & 016 & $\begin{array}{l}\text { Характеристики общества и культуры. Например: } \\
\text { антропология, образование, вероисповедание, } \\
\text { демографические данные, преступность и правосудие }\end{array}$ & 47569 & 0 \\
\hline $\begin{array}{l}18 \text { Здания и } \\
\text { сооружения/Structure }\end{array}$ & 017 & $\begin{array}{l}\text { Конструкции, возведенные человеком. Например: здания, } \\
\text { музеи, церкви, фабрики, дома, памятники, магазины и т.д. }\end{array}$ & 5778 & 0 \\
\hline 19 Транспорт/Transportation & 018 & $\begin{array}{l}\text { Описание различных видов транспорта. Например: дороги, } \\
\text { аэропорты, навигационные маршруты, тоннели, } \\
\text { навигационные карты, транспортные средства, полетные } \\
\text { карты, железная дорога }\end{array}$ & 23523 & 71114 \\
\hline $\begin{array}{l}20 \text { Инженерные } \\
\text { коммуникации/Utilities/ } \\
\text { Communication }\end{array}$ & 019 & $\begin{array}{l}\text { Инженерные коммуникации и телекоммуникационная } \\
\text { инфраструктура. Например: сети энерго- и водоснабжения, } \\
\text { канализация, связь, линии радиосвязи, газопроводы, каналы } \\
\text { передачи данных }\end{array}$ & 5220 & 0 \\
\hline
\end{tabular}

Примечания:

* Сервис, а не данные, неверно отнесенный к предметной области «Данные наук о Земле». Его место - предметная область «Картография»

** Веб-приложение

**** Включает, наряду с картографическими топографическими и навигационными материалами, непространственные данные (стандарты, инструкции и т.п.) 
Заключение. Роль научно-образовательного сообщества в становлении и развитии ИПД. Приведенный анализ был бы не полон и односторонен, если бы мы ограничились вертикальной линейкой ИПД, национального, регионального и локального уровней. В стороне от этой вертикали успешно развиваются ИПД другого типа: ведомственные, отраслевые, корпоративные, научные и образовательные. Из немногих примеров можно назвать академическую ИПД, которая, правда, остается на уровне формулировки стратегии и экспериментов. В основе ее лежит идея интеграции научных исследований, объединение пространственных данных и геосервисов, высказанная впервые в 2008 г. [Кошкарев, Антипов, Батуев и др., 2008] и развиваемая далее [Бакланов, Ермошин, Комедчиков и др., 2011; Кошкарев, Ряховский, Серебряков, 2010; Комедчиков, Кошкарев, Медведев, 2013]. Из примеров ее реализации можно назвать работы по интеграции данных по особо охраняемым природным территориям [Атаева, Кошкарев, Медведев и др., 2011] и использование свободно распространяемых данных в облачной среде [Кошкарев, Медведев, Поликарпов, 2012], разработку геопорталов для инвентаризации и поиска данных, включая ГеоМЕТАИГРАН Института географии РАН (http://asdi.igras.ru) на базе геопортала геоинформационно-аналитической системы «ГеоМЕТА-ВЦ РАН» (http://www.geometa.ru) [Кошкарев, Медведев, 2012]. Аналогичные работы ведутся в Сибирском и Дальневосточном отделениях РАН, а также в вузах [Ротанова, Воробьев, Оскорбин, 2013]. Известен пример реализации образовательного локального геопортала территории базы учебных практик «Сатино» [Осокин, 2009]. И это далеко не все, что может давать и дает научно-образовательное сообщество в «копилку» ИПД. Достаточно упомянуть концептуальные основы ИПД РФ и региональных ИПД, стандарты, разрабатываемые совместными усилиями науки и бизнеса, требования. Наука - основной производитель тематических данных. Все это свидетельствует о высоком, но недоиспользованном и недовостребованном потенциале науки, в том числе академической и вузовской, имея в виду сотни учреждений вычислительно-математического, информационно-технологического, географического и геоэкологического профиля, где использование геоинформационных технологий давно стало обычным делом. В привлечении научных ресурсов как краеугольного камня современной государственной научнотехнической политики видится один из путей повышения эффективности работ в области ИПД в целом.

\section{ЛИТЕРАТУРА}

1. Антипов А.В., Кошкарев А.В., Потапов Б.В., Филиппов Н.В. Единое геоинформационное пространство города Москвы как составная часть инфраструктуры пространственных данных Российской Федерации. Часть 1 // Под ред. А.В. Антипова. М.: ООО Издательство «Проспект». 2013. - 224 с.

2. Атаева О.М., Кошкарев А.В., Медведев А.А., Серебряков В.А., Теймуразов К.Б. Информационная веб-система интеграции данных по особо охраняемым природным территориям. Геоинформационные технологии для территориального планирования и управления. ИнтерКарто/ИнтерГИС 17: Устойчивое развитие территорий: теория ГИС и практический опыт. Материалы Международной конференции, Белокуриха, Денпасар (14-19 декабря 2011 г.). - С. 330-332.

3. Бакланов П.Я., Ермошин В.В., Комедчиков Н.Н., Кошкарев А.В., Краснопеев С.М., Ротанова И.Н., Серебряков В.А., Тикунов В.С., Хромова Т.Е. Геоинформационные технологии для территориального планирования и управления. ИнтерКарто/ИнтерГИС 17: Устойчивое развитие территорий: теория ГИС и практический опыт. Материалы Международной конференции, Белокуриха, Денпасар (14-19 декабря 2011 г.). - С. 147-150.

4. Комедчиков Н.Н., Кошкарев А.В., Медведев А.А. Академическая инфраструктура пространственных данных и новый этап развития геоинформатики // Информатизация географических исследований и пространственное моделирование природных и социально-экономических систем. - М.: Товарищество научных изданий КМК, 2013. - С. 57-72.

5. Кошкарев А. В. (а) Геопортал как инструмент управления пространственными данными и геосервисами // Пространственные данные, 2008, № 2. - С. 6-14. Копия: http://www.gisa.ru/45968.html.

6. Кошкарев А. В. (б) Функции геопорталов в инфраструктуре пространственных данных. ИнтерКарто/ИнтерГИС 14: Устойчивое развитие территорий: теория ГИС и практический опыт. Материалы Международной конференции, Саратов, Урумчи, 24 июня-1 июля 2008 г. Т.II. - С. 214-222.

7. Кошкарев А. В. (в) Эффективное управление пространственными метаданными и геосервисами в инфраструктурах пространственных данных // Пространственные данные, 2008, № 1. - С. 25-32. Копия: http://www.gisa.ru/44539.html.

8. Кошкарев А. В., Антипов А. Н., Батуев А. Р., Ермошин В. В., Каракин В. П. Геопорталы в составе инфраструктур пространственных данных: российские академические ресурсы и геосервисы // География и природные ресурсы, 2008, № 1. - С. 21-31.

9. Кошкарев А.В. (а) Геопорталы и карты эпохи инфраструктур пространственных данных. ИнтерКарто / ИнтерГИС 15: развитие территорий: Теория ГИС и практический опыт. Материалы Международной конференции, Пермь, Гент, 29 июня - 5 июля 2009 г. - Т. 1. - С. 242-246.

10. Кошкарев A.В. (б) Директива INSPIRE и национальные инициативы по ее реализации // Пространственные данные, 2009, №2. - С. 6-11. Копия: http://www.gisa.ru/54638.html.

11. Кошкарев А.В. Инфраструктура пространственных данных и перспективы развития геоинформатики и картографии // ИнтерКарто/ИнтерГИС-16. Устойчивое развитие территорий: теория ГИС и практический опыт: Материалы Международной научной конференции (Ростов-на-Дону (Россия), Зальцбург (Австрия)). - Ростов н/Д: Изд-во ЮНЦ РАН, 2010. - С. 451-456. 
12. Кошкарев А.В. Инфраструктуры пространственных данных: текущее состояние и проблемы. Российский и зарубежный опыт //- Охрана окружающей среды и природопользование, 2011 , № 3. - C. 37-47.

13. Кошкарев А.В. Нормативная правовая база и стандарты европейской программы INSPIRE как основа ИПД РФ. Геоинформационные системы в здравоохранении РФ: данные, аналитика, решения: труды 1-й и 2-й Всероссийских конференций с международным участием, Санкт-Петербург, 26-27 мая 2011 г. и 24-25 мая 2012 г. - Санкт-Петербург: ООО «Береста», 2013. - С. 123-130.

14. Кошкарев А.В. Нормативная правовая база и стандарты инфраструктур пространственных данных. V международная конференция «Геоинформационные технологии и космический мониторинг», Всероссийское совещание консорциума «Университетские геопорталы - УНИГЕО» (2-6 сентября 2012 г.). Ростов-на-Дону: Издательство Южного федерального университета, 2012. - С. 20-37.

15. Кошкарев А.В. От первых инициатив по созданию инфраструктур пространственных данных - к Директиве INSPIRE // Вестник геодезии и картографии, январь 2014 г. - С. 2.

16. Кошкарев А.В. (в) Пространственные метаданные и геопорталы как средства интеграции геоинформационных ресурсов и сервисов // Изв. РАН, сер. геогр., 2009, №1 - С.121-123.

17. Кошкарев А.В., Медведев А.А. Сетевые геосервисы Академической ИПД. Географические исследования молодых ученых в регионах Азии: материалы молодежной конференции с международным участием (Барнаул - Белокуриха, Барнаул, 20-24 ноября 2012 г.) / Ред. О.В. Останин, Н.Ф. Харламова. Барнаул: ООО «Алтай-Циклон». - 2012. - С. 15-18: http://www.asu.ru/files/documents/00006764.pdf.

18. Кошкарев А.В., Медведев А.А., Поликарпов С.А. Виртуальная ГИС-лаборатория как инструмент анализа пространственных данных // Труды Института системного программирования РАН. 2012. - Том 23. - С. 245-255. Копия: http://www.ispras.ru/ru/proceedings/docs/2012/23/isp_23_2012_245.pdf.

19. Кошкарев А.В., Медведев А.А., Серебряков В.А. Данные и сервисы Академической ИПД. ИнтерКарто-ИнтерГИС-18: Устойчивое развитие территорий: теория ГИС и практический опыт. Материалы международной конференции / Редкол.: С.П. Евдокимов (отв. ред.) [и др.]. Смоленск, 26-28 июня, 2012 г. Смоленск, 2012. - С. 153-156.

20. Кошкарев А.В., Ротанова И.Н. Проблемы российских региональных ИПД. Геоинформационное картографирование в регионах России: материалы V Всероссийской научнопрактической конференции (Воронеж, 19-22 сентября 2013 г.) / Воронежский государственный университет. - Воронеж: Изд-во «Цифровая полиграфия», 2013. - С. 77-90.

21. Кошкарев А.В., Ряховский В.М., Серебряков В.А. Инфраструктура распределенной среды хранения, поиска и преобразования пространственных данных // Открытое образование, 2010, № 5. - С. 6173.

22. Кошкарев А.В., Тикунов В.С., Тимонин В.С. Геопортал «Демография»: методика и технологии картографирования // Геодезия и картография, 2010, № 1. - С. 24-31.

23. Осокин С.А. Задачи и методика создания локальных инфраструктур пространственных данных // Геодезия и картография, 2009, № 2. - С.28-32.

24. Ротанова И.Н., Воробьев К.В., Оскорбин Н.М. Принципы построения, технологии и программное обеспечение региональной модели инфраструктуры пространственных данных Алтайского края // Известия Алтайского государственного университета, № 1/1 (77), 2013. - С. 143-147.

25. Создание и развитие инфраструктуры пространственных данных Российской Федерации. Аналитический отчет о создании и функционировании инфраструктуры пространственных данных ЕС (п. 1 календарного плана к Государственному контракту № ГК-187-ОФ/Д01 от 15.11.2011 г.). ФГУП «ФКЦ «Земля», Москва, $2011 . \quad-\quad 428 \quad$ с.: http://aisup.economy.gov.ru/pubportal/downloadfile?uuid=pprtflo2k03380000jc5okvj9t90uut0.

\title{
ГЕОИНФОРМАЦИОННОЕ МОДЕЛИРОВАНИЕ ДИФФУЗИИ ИННОВАЦИЙ
}

\author{
С. А. Тесленок, А. М. Носонов, К. С. Тесленок \\ ФГБОУ ВПО «Мордовский государственный университет им. Н.П. Огарева», Географический \\ факультет \\ ул. Советская, 24, г. Саранск, Россия, 430011 \\ E-mail:kirilltesl@mail.ru,artno@mail.ru,teslserg@mail.ru
}

\section{GEOINFORMATION MODELING THE DIFFUSION OF INNOVATIONS}

\author{
S. A. Teslenok, A. M. Noconov, K. S. Teslenok \\ N. P. Ogarev Mordovian State University, Faculty of Geography \\ Sovetskaya St., 24, Saransk, Russia, 430011 \\ E-mail:kirilltesl@mail.ru,artno@mail.ru,teslserg@mail.ru
}

